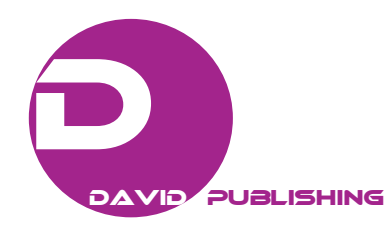

\title{
A Case Study of Affordable Housing in a Medium-Sized City in Central China
}

\author{
Junzhe Wan and Zongbo Tan \\ School of Architecture, Tsinghua University, Beijing 100084, China
}

\begin{abstract}
The main task of this paper is to explore the housing condition and housing policy in the vast but long-neglected middle-sized cities in China. Under the requirement of "Construction of 10 Million Units in 2011" from the central government, the affordable housing has started its nationwide building. Medium-sized cities are facing different developing periods but applying same housing policy as big cities. The paper examines the economic and social condition of the case city to find out the housing problems. It concludes that houses are affordable in these medium-sized cities, but housing policies are not implemented well. The paper proposed that housing affordability in medium-sized city is not about quantity but about quality. To keep houses affordable in these medium-sized cities, housing market, legislation, urban planning, public participation and intensive developments are all important.
\end{abstract}

Key words: Affordable housing, medium-sized city, housing plan.

\section{Introduction}

\subsection{Housing Policy All over the Country}

Accompanying the rapid urbanization of China, as Beijing, Shanghai, Shenzhen and other developed cities having shown a disorder in real estate market and a severe shortage of housing after 2003, according to China Statistical Yearbook, housing prices had increased $115 \%$ nationwide from 2003 to 2010. The long-term accumulated social intension burst out, so that affordable housing has been endowed political and social significance and made a most attracting topic both in academics and in society around 2011.

Zou [1] has provided an overview of the housing programs launched by Chinese government and pointed out the contradiction in its housing policy. The current housing policy of China had endured fundamental changes after the 1980 housing market reform [2] and contains several components. The earliest affordable housing is economical housing, with the target group as middle income families, dating back to 1990 s and firstly constructed in the

Corresponding author: Junzhe Wan, Ph.D. candidate, research fields: urban planning and housing policy. E-mail: wanjz05@mails.tsinghua.edu.cn. developed cities. The word economical means "commodity housing with a small profit margin" [3], and the local government would decide the location and price of the houses, and the housing developer could get the land with relatively low prices. The construction of economical housing slowed down after 1999 [4]. Afterwards, a new series of affordable housing such as the house of two limits (house with limited price and area), the social housing (baozhangfang, which means government would provide some security for the residence in Chinese), the public rental housing (gongzufang, which refers to houses owned by government but rented to low-income families in low rent) and the live type commercial housing (which means people cannot rent it out or sell it). Some scholars used methodologies of economics, public management science and sociology, especially the mathematical models to analyze the housing prices and the residential housing affordability in several big cities such as Beijing, Shanghai $[5,6]$, and all over the country $[7,8]$.

\subsection{Neglected Middle-Sized Cities}

Despite the housing shortage in varying degrees all 
over the country, housing problems emerging in cities such as Beijing have not appeared in most of the medium and small cities. On the contrary, many of Chinese cities have reached a high level of "home ownership". 1

The word "middle-sized" have different standards. The traditional classification usually divided cities by the number of registered population. ${ }^{2}$ Lin examined the relationship between the growth of Chinese cities and the national strategizing, and classified cities by non-agricultural population [9]. The CBN (China Business Network) Weekly has conducted the classification of Chinese cities according to their comprehensive performance including economy, transportation, education, commerce and so on. ${ }^{3}$ Four hundred cities (including 300 prefecture-level city and 100 strong counties) out of the 661 Chinese cities were examined and divided into five classification, as shown in Fig. 1.

No matter how the cities were divided, the research focus of housing policy has been concentrated on the top part of the pyramid. Current papers are mostly concentrated on the overall condition of Chinese housing problem and the housing policy from central government. With all the differences of urban scale and economic level, is it reasonable that we apply the housing policy designed for the big cities to those less developed ones? Does the rental market still work well and is it enough for the housing needs of local and floating population? Did the large quantities of affordable housing do help the poor people? Are they necessary or superfluous?

\subsection{Research Processes}

To answer these questions, data analysis, policy analysis and field research are key methods of this

\footnotetext{
${ }^{1}$ A survey conducted by several research centers showed that the highest home ownership rate in capital cities was $90.1 \%$ of Changsha City. The home ownership rate in big cities like Shanghai was around $70 \%$, which is the lowest all over the country, http://house.focus.cn/news/2012-06-05/2046841.html.

${ }^{2}$ http://chinadataonline.org/member/city/city_md.asp.

${ }^{3} \mathrm{http}: / / \mathrm{www}$. cbnweek.com/v/article? $\mathrm{id}=6245$.
}

paper. Main materials are the public statistics provided by the government, including the sixth national census and statistic year book, and the field survey data obtained by the authors. The operation, construction and distribution of affordable housing are important. The contribution of this paper is threefold: (1) It takes the middle-sized cities of China into the scope of housing policy for the first time; (2) It argues the defect of the current housing policy through analyzing; (3) It provides experience for the future design of housing policy in China.

This paper is organized as follows: Section 2 gives brief facts about the case city and explains the reason choosing it; Section 3 elaborates the social development level and housing condition; Section 4 examines the implementation of housing policy in the case city; Section 5 discusses what kind of housing policy we need in medium-sized cities and what should we do.

\section{The Case City}

The case city is a prefecture-level city in a big agricultural province located in the central China, just a normal city like other central region cities. It is composed of two municipal districts, one county-level city and six counties, with an entire area of $10,704 \mathrm{~km}^{2}$ and a total resident population of $7,350,000$ people.

\subsection{A Traditional and Typical Agricultural City}

The case city used to enjoy a high level of civilization and had a 5,000 years long history because of the location and environmental advantages in the old times. However, the city became less important and affluent after Southern Song Dynasty (1127 AD) due to the frequent wars between the north-western minorities and the Han nationality. Agriculture has been the main industry of central China, but the land fertility was obviously lower than the southern part of China ever since. The reform and opening up in 1978 gave the eastern coastal area an 


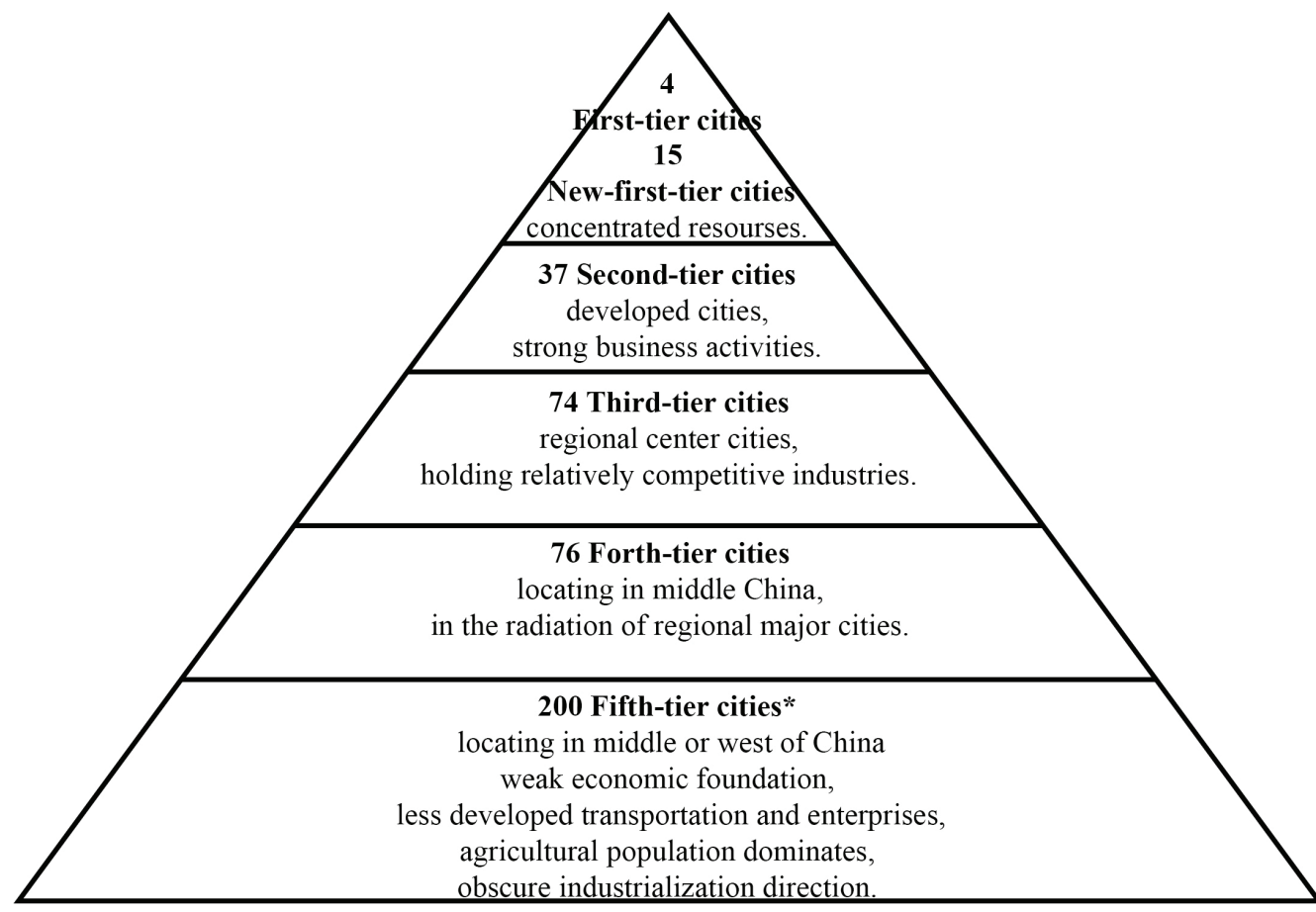

* The case city was classified into the Fifth-tier cities.

Fig. 1 City classification, 2013.

opportunity to develop their industries, while the central part of China, including the case city, remained as agrarian regions. Therefore, it is a big provider for peasant workers. Approximately 12\% population of the province are peasant workers outside the province, while another $12 \%$ are farmers working in cities within the province.

A turning point came in 2011, in which year the State Council announced "The Guidance to Accelerate the Construction of the Central Plains Economic Zone", tried to incite the industrialization of central regions. Although people expected the economic increase in the recent future, but the urbanization level of these cities were quite stable. Could the case city benefit from this central policy? The answer is yes, but the planned airport which was said to be finished by 2014 was still a blueprint. Also, so far, the city had been unable to share the bonus of Chinese rapidly extended high-speed rail network. The big station is still under construction.

The city located in the junction of four provinces, and the external transport was quite broad, with tens of national and regional roads and traditional railways (Table 1 ).

\subsection{Why the Case City Is Chosen?}

We chose the city as a case for the following reasons:

(1) It is a typical medium-sized city with a moderate area and population. According to official statistics, among the 9 million total population (while the residents population is 7.28 million), its urban population are around 2.5 million by the end of 2013, therefore the urbanization rate is $28.3 \%$. In either way

Table 1 The external transport of the case city.

\begin{tabular}{lll}
\hline \multicolumn{2}{l}{ Transportation forms } & Number \\
\hline \multirow{3}{*}{ Railroad } & State route railways & 2 \\
& State route high-speed rail & 4 \\
& Local regional rail & 3 \\
\hline \multirow{4}{*}{ Road } & State road & 3 \\
& National trunk highway & 2 \\
& Provincial highway & 12 \\
& Local high-speed & 9 \\
\hline \multirow{2}{*}{ Air traffic } & Airport & 1 (under construction \\
& & since 2011) \\
\hline
\end{tabular}


of classification, the case city is classified in the middle-sized cities;

(2) The case city still stays in the primary stage of urbanization at this period and this is common with many other cities which are totally different from the metropolises in China;

(3) The city locates in the center of China, hence, its external environment and economy level could represent most of the cities in the central plains region;

(4) The discussion of this paper focuses on the two municipal districts of this city. The two municipal districts are the most urbanized area of the whole city. Therefore, if the housing policy is not suitable for them, it is certainly not suitable for other counties either.

\section{Social Development Level and Housing Condition in the Case City}

3.1 Economical Aspects: Agrarian Structure and Current Dilemmas

The case city owned a GDP (gross domestic product) in 2013 for about 153.8 billion yuan and ranks in the middle of its locating province. If we compare this number with all the capital cities in China, we could find that it ranks 33 out of 36 , and the GDP of Shanghai, the most economy developed city in China, could be 14 times of this city, as shown in Fig. 2. Though the city's GDP is stably increasing, the new policy in 2011 seems of little influence on the growth rate, as shown in Fig. 3.

The city remains a relatively low level of urbanization. According to the official figures, the average urban proportion of the province is $43.8 \%$, while the case city holds a much lower number, $28.3 \%$. If we calculate it using the registered population, the number would be much lower, only $14 \%$. The province has experienced a relatively faster urbanization, for the urbanization rate of the province in 2010 was $38 \%$, while that of the city was $27.8 \%$. As mentioned, the province has been exporting peasant workers to the metropolises and the case city is far less attracting to the peasant workers.

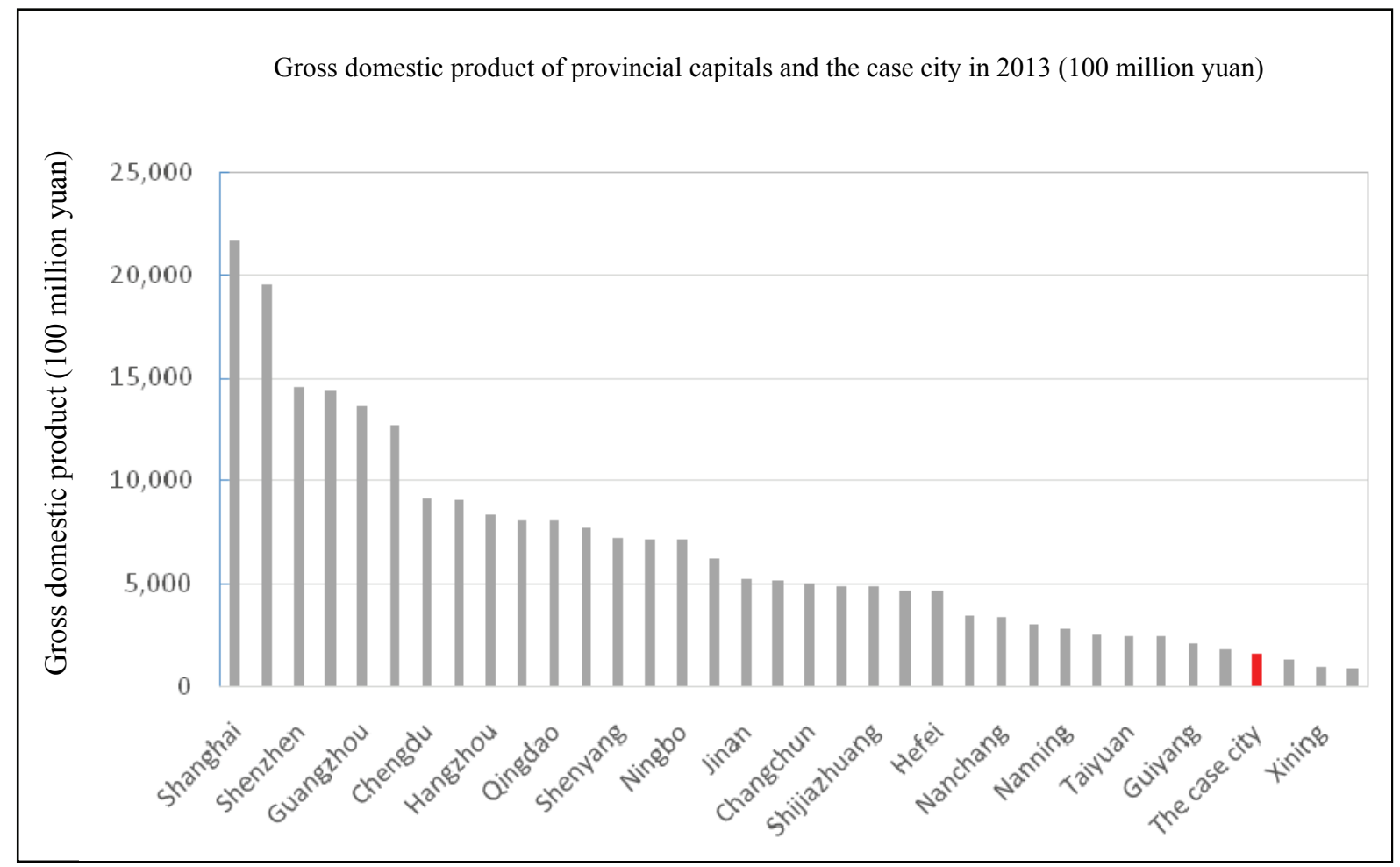

Fig. 2 The GDP comparison between the case city and the national capital cities. 


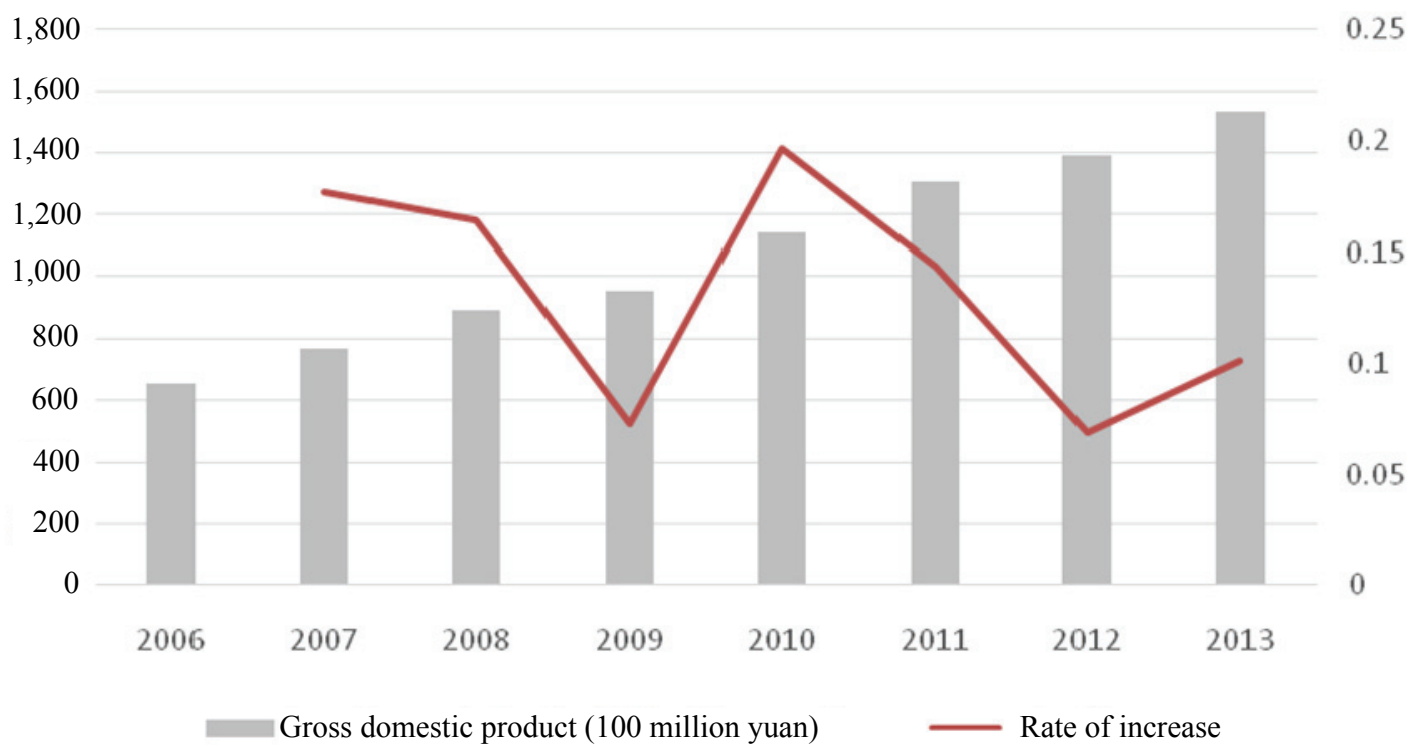

Fig. 3 The GDP growth of the case city from 2006 to 2013.

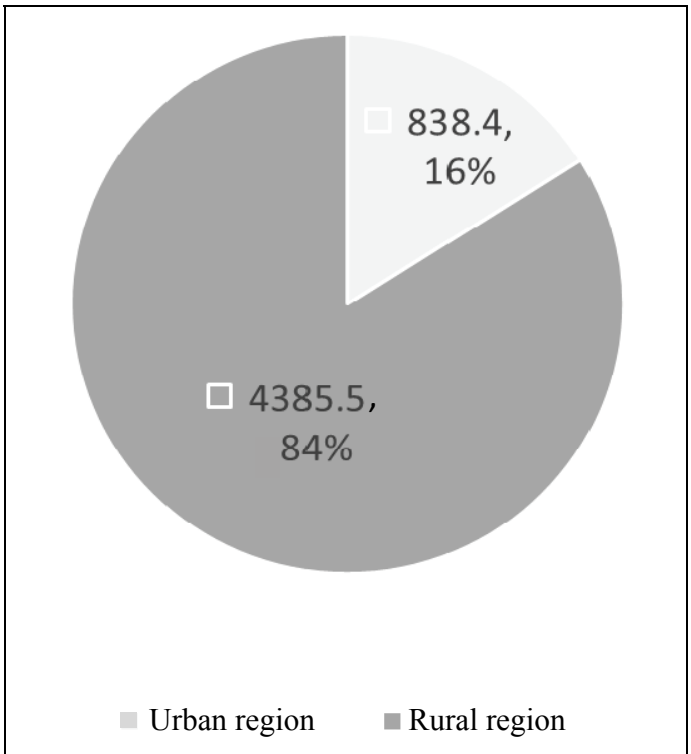

(a)

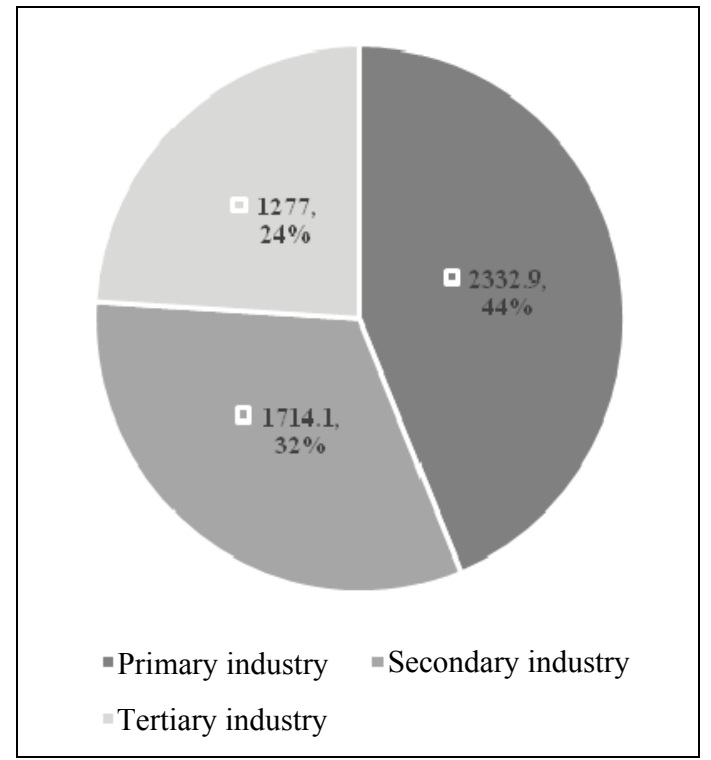

(b)

Fig. 4 The employment in: (a) urban and rural regions; (b) by three industries (thousand people, 2013).

At the same time, the city's economic structure is also agrarian. With a total employed labor of 5.22 million people, only 0.84 million $(16 \%)$ of that working in the urban area. The three parts of the GDP, primary, secondary, tertiary industry, hold a ratio near $1: 2: 1.38$, and the people who work for these three kinds of industries are $1.8: 1.3: 1$. Since so many working people are scattered in rural area, the housing demand in urban area was far less than that of Beijing or Shanghai, as shown in Fig. 4.

There are mainly two dilemmas in the development of the case city's industry. One is that the city did not have unique comparative advantages. The only natural source, a coal mine, is in the charge of an administrative-independent county-level city. The enterprises' performances are barely satisfactory. Although the government sets up several industrial parks and provides enough discount in rental prices 
and tax, the parks still seem not attractive because of the inner location and weak social foundation. The current industries are quite initial ones like cigarette lighter making, steel tape manufacturing, primary wood processing, foods and drinks production and so on. That is the reason why the affluent labor force prefers higher paid jobs in bigger cities. The other problem lied in the gloomy future of tourism. There are several registered high-ranking humane sightseeing spots in the city, but most of them are reconstructed in the past 20 years to absorb tourists. The remains of city' long history have been heavily destroyed after hundreds of years' war, while the natural scenic spots have no distinguishing fame. However, China has so many other ancient capitals or famous natural scenic spots which are preserved much better. With the inauthentic buildings and the poor tourist service, the case city cannot even compete with other famous tourism cities in the same province. The transition and urbanization of the city are facing difficulties indeed.

\subsection{Social Aspects: Initial Period of Civic Education, Public Service}

The detailed statistics of education population about the city are unavailable. We extrapolate its general condition from the data of the province. According to the sixth national census, the province's population of higher education was only $71 \%$ of the national average level. $42.5 \%$ of the province population stopped their study when finishing nine-year compulsory education, but this is better than other regions, where people give up studying after primary school, as shown in Fig. 5.

The higher education resources of this city could be described as scarce. This higher education trained 26,000 students in 2013 and there is only one ordinary university ${ }^{4}$ in the case city providing higher education

\footnotetext{
${ }^{4}$ The universities in China are divided into three levels. The highest level is key university, among which there are 985 and 211 universities. Ordinary universities are lower level
}

before 2011. The university used to be a junior college and was reorganized in 2000 and then obtained the qualification to authorize the bachelor's degree in 2004. Another two ordinary universities were established in 2011, being the third level in Chinese university system. Besides, there are three vocational-technical colleges. The certifications they provide are uncompetitive, but better than those from adults' education colleges which usually used as a necessity for a blue-collar occupation. The higher education condition of the whole province is not optimistic, because only one university was 211 university and no 985 universities exist. ${ }^{5}$ If the students can get a high score in the NCEE (national college entrance examination), they will of course choose a better university other than the local ones. That produces a brain drain in the city and the province, making the development even harder.

When looking through the overall public situations, we find out that the case city has an average performance among cities in the province. The most unsatisfying aspects are the per capita area of roads, the number of culture, sports and entertainment institutional units, and the number of community service facilities. So far, the case city cannot provide enough facilities for civil culture life.

\subsection{Housing Condition of the Municipal Area}

The two municipal districts are the traditional and current city center. The busiest railway station is located north of the urban area, making this station the center of commerce. The former sites of all key governmental departments were laid around the station. However, the new city center was transferred to the southern part of these two districts, and new sites for those schools and public organizations were moved southward.

The land for housing supply is quite sufficient from

universities. The lowest level contains secondary colleges and independent colleges.

${ }^{5} 985$ universities and 211 universities are two groups of good universities selected by the Ministry of Education. They are important evaluation standard for Chinese universities. 


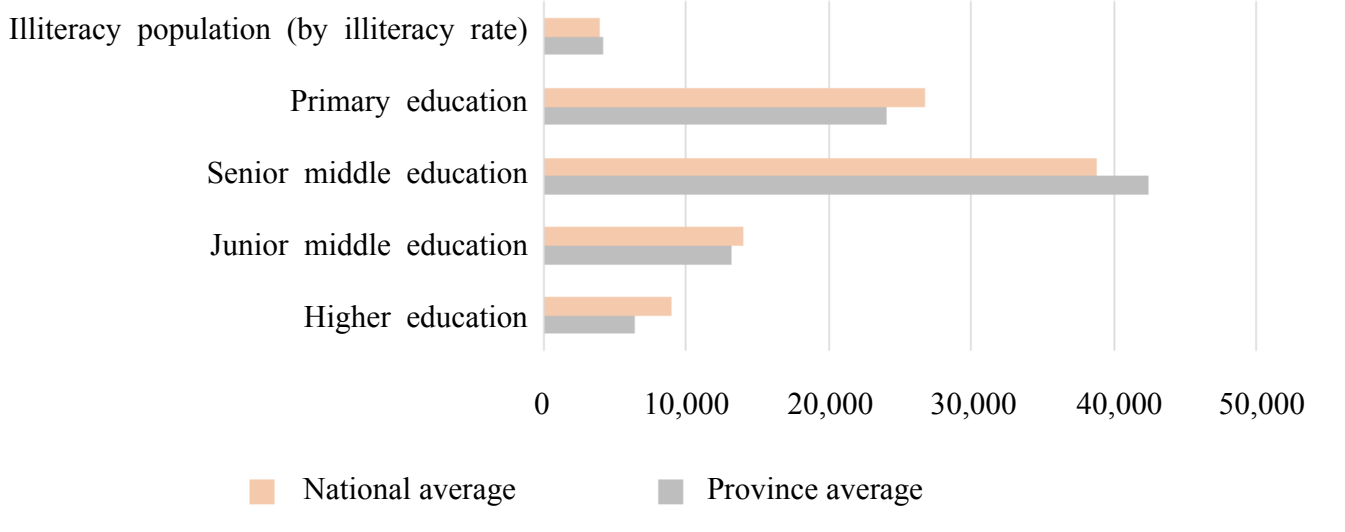

Fig. 5 The education population by level (every 100,000 people).

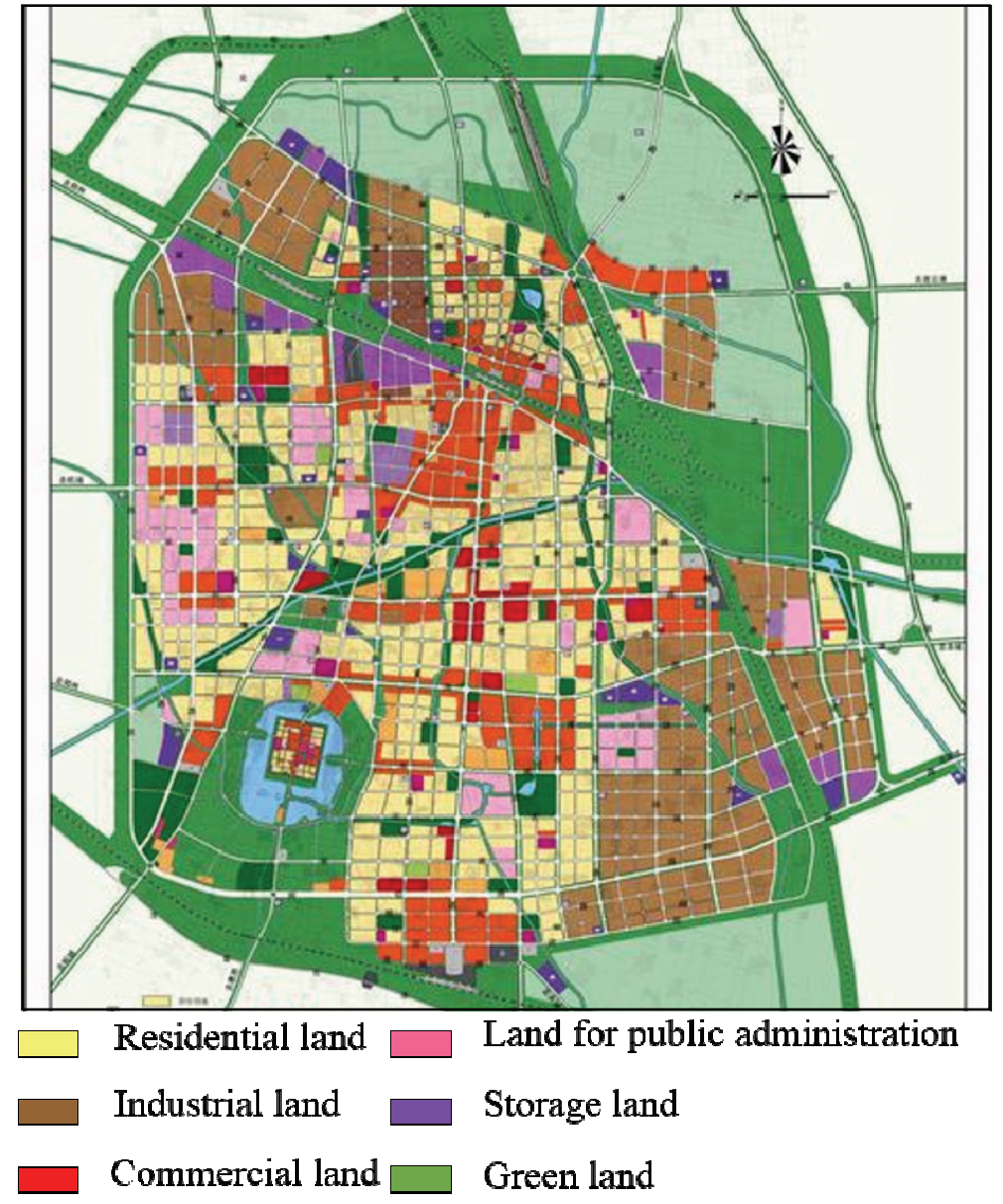

Fig. 6 The master plan of the two municipal districts.

the master plan of the city. Almost half of the built-up area is for residential, as shown in Fig. 6. Another evidence comes from the large scale of vacant and overstock houses. Different from the usual situations in big cities, we find that many of the new houses cannot sell. The government mentioned in a news that only $60 \% \sim 70 \%$ of built houses could be sold out. Second-hand houses are not popular at all.

The housing prices are from 2,000 6,000 yuan $/ \mathrm{m}^{2}$. It is much narrower range than that of metropolises 
and has been stable in the last 5 years. ${ }^{6}$ According to official news, the average housing price is 3,500 yuan $/ \mathrm{m}^{2}{ }^{7}$ The prices fluctuate slightly depending on the location. The prices are quite stable in the whole region, while the houses near the city center are higher than other places. The commercial houses sold in the two municipal districts cannot be obtained, so we take the data from the province's statistic year book to explore the overall trends of the real estate market. The total areas of commercial houses sold from 2006-2013 are shown in Fig. 7. The real estate market is developing drastically in recent years, especially in the big-sized apartment market. This seemed to be inconsistent with the per capita floor space in the city in the statistic year book, which is $31.6 \mathrm{~m}^{2}$. The case city holds a relatively low level in the province.

In the marginal area of the two municipal districts, land expropriation and bungalow building exists at the same time. When the urban area expands, some small spots of self-help houses remain in the city, just as how chengzhongcun (village in the city in Chinese) formed in Guangzhou. Therefore, the city appears as the mixture of the real estate projects and the bungalows, rather than a uniform configuration of new buildings.

\subsection{Housing Affordability in the Case City: A Well} Working Housing Market and Normal Quantity of Housing Demand

To examine the housing affordability in the case city, a discussion has to be laid about the term's definition. Many scholars such as Kutty [10] and Stone [11], had fully elaborated the multiple meanings of housing affordability. How to obtain the housing affordability? Gan and Hill [12], Suhaida et al. [13] and Mulliner et al. [14] have brought up multi-dimensional methods. Mak et al. [15], Cai and $\mathrm{Lu}$ [16] also discussed the case of China. A frequently used indicator, also a simple one, to examine the housing affordability is the ratio of housing cost to

\footnotetext{
${ }^{6} \mathrm{http}: / /$ newhouse.shangqiu.fang.com/house/s/b26000\%2C8000/.
} ${ }^{7}$ http://www.hnjs.gov.cn/zwdt/sxjsdt/2012-01-05-18085.html. income. The accessible data could be used to get the indicator.

The statistic year book of the province has surveyed the housing expenditures of the average level. Housing expenditure includes the cost of houses itself, the water, electricity and fuel fees, and the service fee for residence. Actually, the pure cost of houses is around $30 \%$ of the total residence expenditure. We decide to use residence expenditure as the housing cost, because the pure cost of houses on average is unexpectedly low, only $2 \%$ of the total disposable income. Therefore, the electricity and water fees, etc. cannot be neglected to make sure that the outcome can reveal the true living condition and housing affordability in the case city. The ratio of housing cost to income is shown in Table 2, at an average of 5.8\%. This is a very low ratio compared with the big cities.

We then try to examine the affordability index among the lower income household, but the number of detailed housing expenditure of each income groups is not accessible. The statistic year book divided the whole province's household into seven income groups, while divided each city's household into five income group. After calculating the province average level, we are amazed to find that, even for the lowest income household, the ratio of $8.93 \%$ is quite acceptable (Table 3). Even if we include the expenditure on household facilities, the ratio does not go beyond $15 \%$.

We can draw the conclusion that the housing in the case city and even most of the province, is affordable, according to American standard, $25 \%$ in the early 1980 s and $30 \%$ afterwards.

\section{Implementation of Housing Policy in the Case City}

Since central government declared the new 5 years plan on affordable housing in 2011, the case city, as many other cities in China, immediately made a housing plan to respond. 2011 is the starting point of affordable housing in most of Chinese cities. Housing 


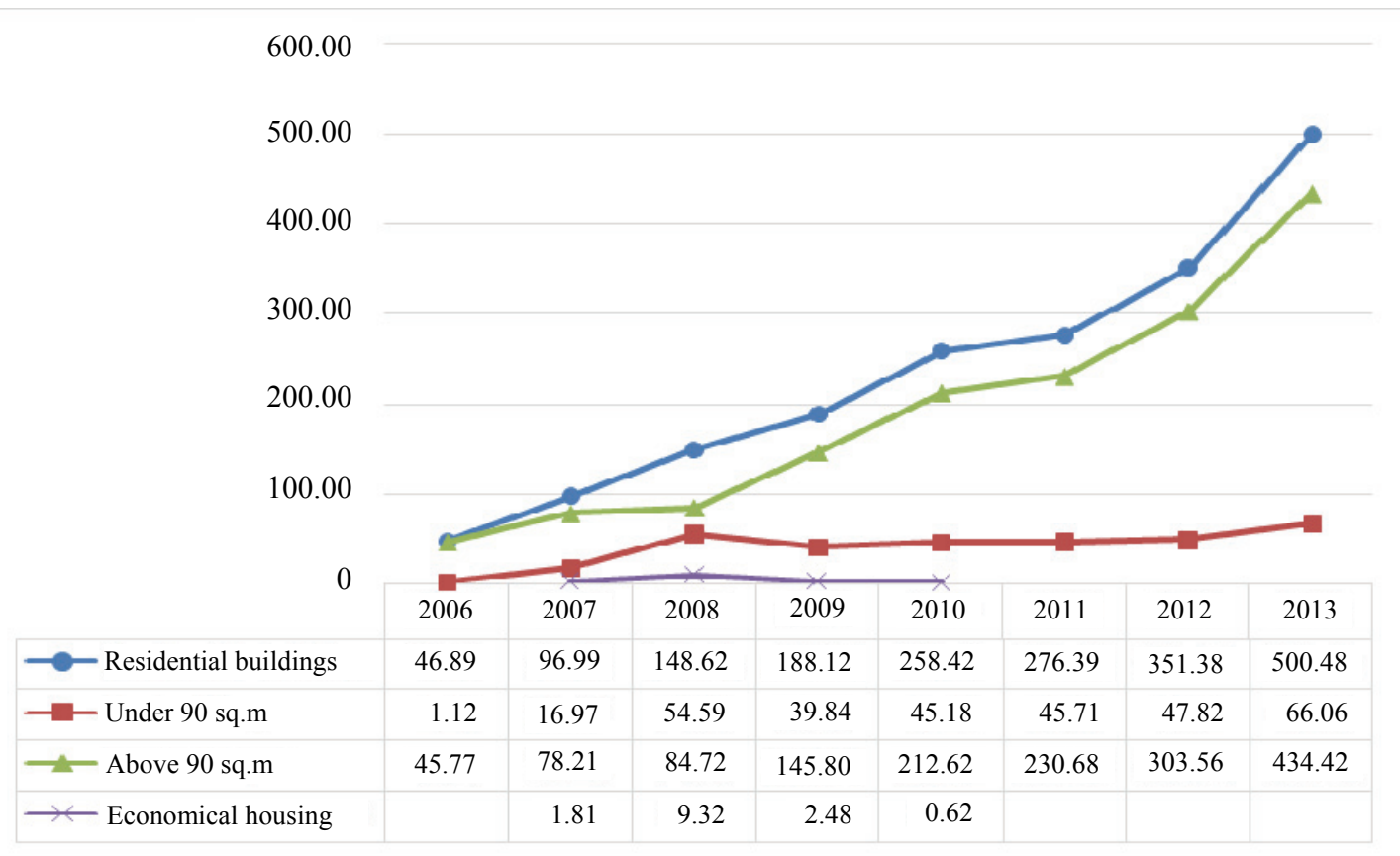

Fig. 7 The floor space of commercial houses sold in the whole city by year $\left(10,000 \mathrm{~m}^{2}\right)$.

Table 2 The ratio of housing cost to income in the case city from 2008-2013.

\begin{tabular}{lllllll}
\hline Per capita (yuan) & \multicolumn{5}{c}{ Year } \\
\cline { 2 - 7 } & 2008 & 2009 & 2010 & 2011 & 2012 & 2013 \\
\hline Average disposable income & 11,752 & 12,715 & 14,178 & 16,151 & 18,312 & 20,214 \\
Total consumption expenditure & $6,969.21$ & $8,034.66$ & $8,733.98$ & 10,361 & 11,936 & 12,604 \\
Expenditure on residence & 696.48 & 719.16 & 933 & 812 & 996 & 1,191 \\
Residence/disposable income & $5.9 \%$ & $5.7 \%$ & $6.6 \%$ & $5.0 \%$ & $5.4 \%$ & $5.9 \%$ \\
\hline
\end{tabular}

Table 3 Housing affordability among low income group in the province and the case city in 2013.

\begin{tabular}{llllllll}
\hline Per capita & $\begin{array}{l}\text { Lowest } \\
\text { income }\end{array}$ & $\begin{array}{l}\text { Low } \\
\text { income }\end{array}$ & $\begin{array}{l}\text { Lower middle } \\
\text { income }\end{array}$ & $\begin{array}{l}\text { Middle } \\
\text { income }\end{array}$ & $\begin{array}{l}\text { Higher middle } \\
\text { income }\end{array}$ & High income & $\begin{array}{l}\text { Highest } \\
\text { income }\end{array}$ \\
\hline Average level of the province & & & & & & & \\
\hline Disposable income & 8,430 & 12,076 & 16,253 & 21,008 & 27,351 & 35,893 & 55,412 \\
Total consumption expenditure & $7,799.02$ & $8,922.3$ & $11,432.25$ & $13,867.29$ & $18,684.22$ & $21,640.37$ & $30,792.49$ \\
Expenditure on residence & 752.67 & 720.62 & 932.03 & $1,195.92$ & $1,704.7$ & $1,839.1$ & $3,073.57$ \\
Residence/Disposable income & $8.93 \%$ & $5.97 \%$ & $5.73 \%$ & $5.69 \%$ & $6.23 \%$ & $5.12 \%$ & $5.55 \%$ \\
\hline The case city & & & & & & & \\
\hline Disposable income & & 11,159 & 16281 & 20,334 & 24,325 & 32,608 \\
Total consumption expenditure & 7848 & 11926 & 11,190 & 16,281 & 17,371 & \\
\hline
\end{tabular}

policy in the case city cannot be described as successful and suitable, as in most medium-sized cities.

\subsection{Different Types Aiming at Different Groups}

There are mainly four kinds of affordable housing-claimed by the government in the case city, which are also being built in other parts of the country
(Table 4). As discussed in Section 1, economical housing was the first kind of affordable housing in China and has been controversial because of the loopholes in its implementation. In fact, the construction of economical housing had been suspended in the case city since 2012. Low-rent housing and public rental housing can help low income 
family with relatively low rent fee. It is said that these two types will be combined into one in the near future. The squatter settlement rebuilt housing aimed at the original residence. This is just what we called "urban regeneration". But tricks usually hide in this progress. The old houses were demolished, leaving the land to the government to build higher and more intensive community, with more commercial buildings designed. Apart from the houses for the original residence, developers can build many other apartments to make profits. And these new apartments are not "affordable" for low income families. Therefore, the affordable housing only consists of the former three types.

The number of affordable housing built in the two municipal districts could be found through the government website, but different government gave different data, and some data are not available, as shown in Table 5. Although the statistics are not complete, the fact that squatter settlement rebuilt houses increases faster than affordable housing is quite clear.

\subsection{Remote Location and Monotonous Apartments}

There were 16 projects of affordable housing built in 2011, most of them are located far from the city center, as shown in Fig. 8. Although the urban area is not so vast to produce big commuting difficulties for the residence, the primitive public transport indeed provide little convenience for them. If the government was going to develop in all directions and ultimately formed a metropolis, the affordable housing being built now would turn out to be in a very good location, just like what had happened to Tiantongyuan and Huilongguan in Beijing [17]. In the next 3 years, the affordable housing was all located in remote areas, even in places where roads had not been built. Even the commercial houses there would be much cheaper and possibly affordable for the low-income citizens. Considering that most of the low-income groups rely on bicycles in their daily life, these houses were absolutely disturbing for them.

Four of the projects were surveyed in this paper (Fig. 7). Three of them were surrounded by farmlands, although they are still located within the urban boundary. Few buses could be seen in the streets. The apartments look quite similar, and the designers did not do any investigation about what people really need (Fig. 9). Most of the houses are vacant. The affordable housing intended to deliver on promises of housing improvement, but it failed.

\subsection{Exclusive Decision-Making Process and Strange Redirection}

From the beginning to now, the decision-making process of affordable housing is exclusive to the public

Table 4 Four kinds of affordable housing in the case city.

\begin{tabular}{|c|c|c|c|c|c|c|c|c|}
\hline \multicolumn{3}{|l|}{ Type } & \multicolumn{2}{|l|}{ Owner } & \multicolumn{2}{|c|}{ Target group } & \multicolumn{2}{|r|}{ Notes } \\
\hline \multicolumn{3}{|c|}{ Low-rent housing } & \multicolumn{2}{|c|}{ Government/public organization } & \multicolumn{3}{|c|}{ Lower income families } & Smaller than $50 \mathrm{~m}^{2}$ \\
\hline \multicolumn{3}{|c|}{ Public rental housing } & \multicolumn{2}{|c|}{ Government/public organization } & \multicolumn{3}{|c|}{ Sandwich class (jiaxinceng) } & Smaller than $60 \mathrm{~m}^{2}$ \\
\hline \multirow{2}{*}{\multicolumn{3}{|c|}{$\begin{array}{l}\text { Economically affordable housing } \\
\text { Squatter settlement rebuilt housing } \\
\text { (not affordable) }\end{array}$}} & \multicolumn{2}{|c|}{ Low-middle income families } & \multicolumn{3}{|c|}{ Low-middle income families } & - \\
\hline & & & \multicolumn{2}{|c|}{ Buyers } & \multicolumn{3}{|c|}{$\begin{array}{l}\text { The original residence and new } \\
\text { buyers }\end{array}$} & - \\
\hline b & & & & & & & & \\
\hline \multirow[t]{2}{*}{ Year } & \multicolumn{2}{|c|}{ Low-rent housing (units) } & \multicolumn{2}{|c|}{$\begin{array}{l}\text { Public rental housing } \\
\text { (units) }\end{array}$} & \multicolumn{2}{|c|}{$\begin{array}{l}\text { Economically affordable } \\
\text { housing (units) }\end{array}$} & \multicolumn{2}{|c|}{$\begin{array}{l}\text { Squatter settlement rebuilt } \\
\text { housing (units) }\end{array}$} \\
\hline & District 1 & District 2 & District 1 & District 2 & District 1 & District 2 & District 1 & District 2 \\
\hline 2011 & 4,969 & 4,592 & 650 & 1,322 & 1,880 & 606 & 1,470 & 450 \\
\hline 2012 & - & 4,776 & - & 0 & & 0 & - & 651 \\
\hline 2013 & 4,442 & 3,932 & 1,030 & 800 & ) & 0 & 4,875 & 774 \\
\hline 2014 & - & 8,682 & - & 0 & & 0 & - & 11,748 \\
\hline
\end{tabular}

${ }^{8}$ Figures are from the government website: http://www.sqzj.gov.cn/html/qzjq/zfbzk/3673.html, http://www.liangyuan.gov.cn/e/ action/ShowInfo.php?classid=87\&id=8249. 


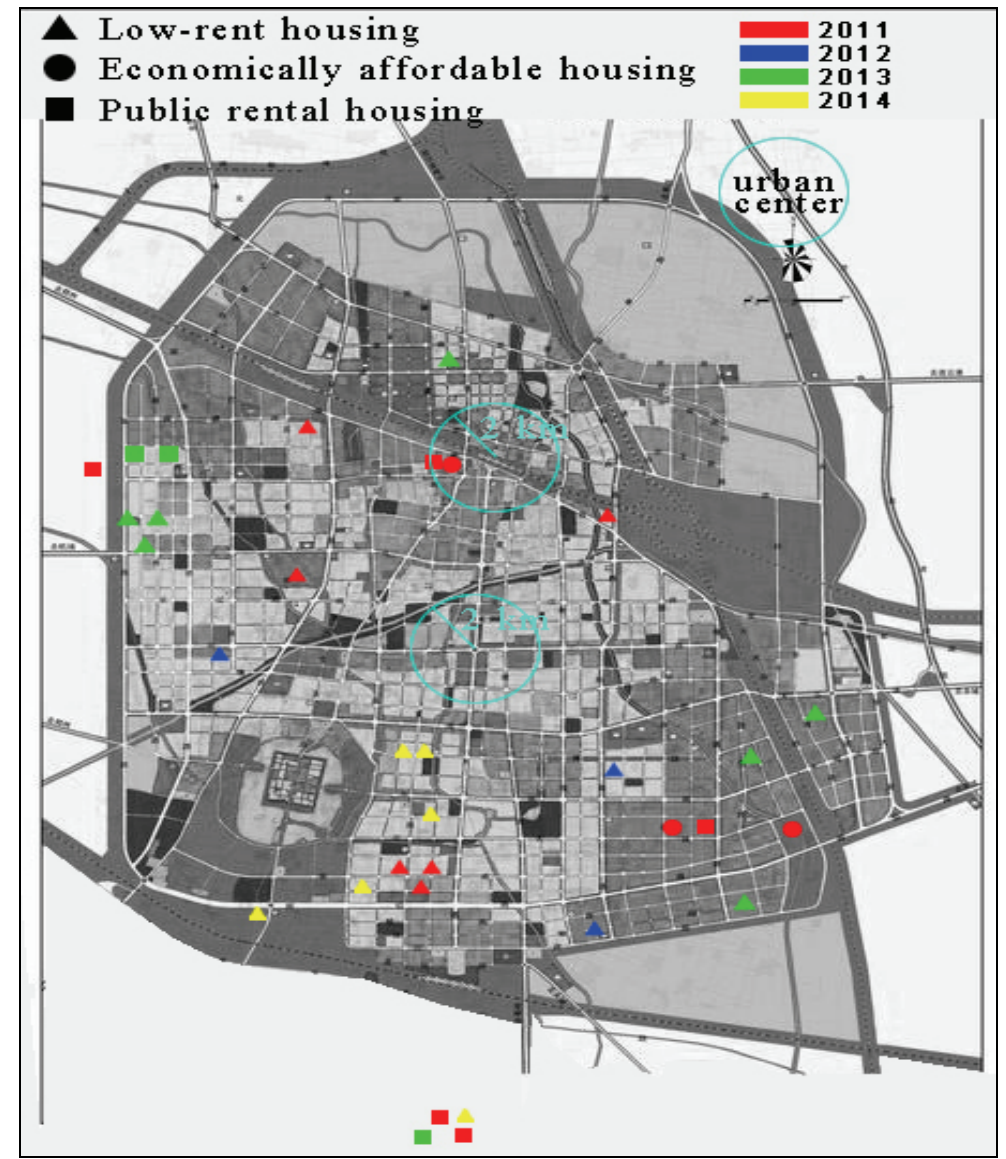

Fig. 8 The affordable housing distribution in the case city from 2011-2014.

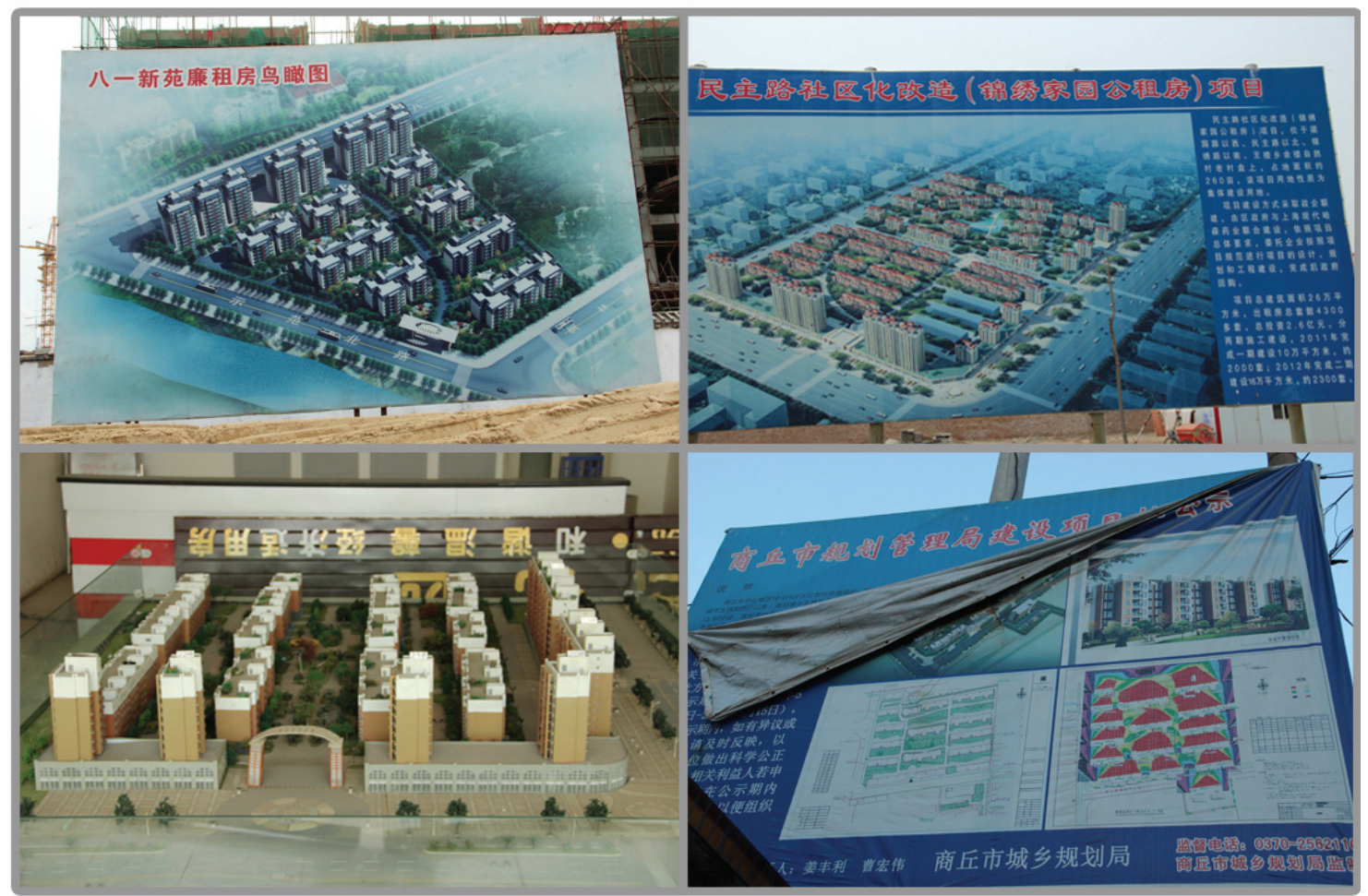

Fig. 9 Four of the affordable housing projects in the two municipal districts. 
in the case city. There is no public participation in deciding houses' number and site selection. The whole process is top-down pattern. From central government to province level, the affordable housing is a political mission rather than market motivation. The low-income families were never given a chance to decide what they want.

Another strange fact is that the government started to sell out the low-rent housing from $2013,{ }^{9}$ which was originally designed as rental houses. It is considered that low-rent housing can do more for low-income families than economically affordable housing because it leaves no loophole on property right. However, the government decided to sell these houses at "cost price", claiming that the purpose was to get money back. How could a low-income family afford such kind of houses? This redirection went to the other side of low-rent housing and is a proof of how unreasonable the affordable housing plan is. Again, no public participation could be found in this change. It all depends on the governments' will. Another explanation is that central government now paid less attention on housing problems and more attention on economic transit of the whole country. Central government and local governments play different roles on solving housing problems, and local governments care more about the economic profits and the income from urban lands [1-3]. Therefore local governments lack motivations to develop its own affordable housing system, especially in medium-sized cities like the case city.

\section{Conclusions and Suggestions}

\subsection{Houses Are Affordable in the Case City and Other Medium-Sized Cities}

The first reason that the case city holds a high housing affordability is that many medium-sized cities are exporting more people to big cities than absorbing people back into their own urban area. As analyzed in

\footnotetext{
${ }^{9}$ http://www.sqrb.com.cn/lydzb/html/2013-07/08/content_2075
} 42.htm
Section 3, the social development level and public service in the case city cannot compare with those of metropolis or capital cities. Most of its citizens prefer to receive higher education in big cities and try to buy a house there. The housing need in medium-sized cities is modest. People who intend to buy a house in such cities are mostly native people, whereas Beijing is attracting the wealthy from all over the country.

The second reason is that houses being built in the case city are quite adequate for its population. It usually spends a long time for a new commercial housing community to sell all its apartments out. According to the government's survey, affected by the economic crisis, the housing vacancy rate in the case city in 2008 is $22 \%$. With this ratio of supply to demand, the housing market in the case city, also most of the medium-sized city, is working well.

Another reason, also a very important one, is the low ratio of renting to selling and stable housing price in the case city. Houses are endowed with investment function in China, and many people buy houses out of speculative purpose. However, the ratio of renting to selling in the case city is around 1:400, which means that house-owners could hardly benefit from renting houses out. Few citizens choose to buy a second house specially for renting in the case city. The stable housing price also prohibits people from buying extra houses to get price difference. This conversely keeps the housing market effective.

\subsection{Current Housing Policy Needs Modification and More Consideration of Utility}

First of all, the housing policy of China should be differentiated according to different types of cities and their housing conditions. For a city as in the case, the policy does not work as predicted. It is meaningless and a waste of resources to build large amount of houses in a less-developed city. Without systematic supervision, this housing construction is susceptible to inappropriate manipulation.

The coordination between urban planning and 
affordable housing was weak. The affordable housing communities were always driven to suburban areas. Even in a medium-sized city, as the case shows, affordable housing was built far away from the city center, with lack of transportation, public service and dweller-friendly design. People who would live in these houses never got an opportunity to state their needs.

\subsection{Do We Need Affordable Housing in Medium-Sized} Cities: Yes, Housing Quality Is Also an Important Factor of Housing Affordability

The affordable housing is to solve housing difficulties — shortage of houses — which concentrated in big cities and rapidly urbanized area. However, in medium-sized cities, housing difficulties are not about quantity, but about quality. Houses are massively built, with normal prices, but none of them is well designed, nor can they survive 20 years usage. On the other hand, the number of relatively low-income group is far less than those of big cities. They do have somewhere to live, but the houses are in bad condition.

The housing quality of China is much lower than some other Asian countries such as Japan or Korea. But this situation is overwhelmed by the shortage of houses in the large cities. In medium-sized cities, people could only buy rough houses with no decorations at all, and the community environment is poor. Houses are not precisely designed even in expensive community. Housing quality should be paid more attention to.

We need affordable housing in medium-sized cities, but not the same way with those large cities. Affordable housing should not be treated as a political mission apart from real life. The point is to make current affordable housing more comfortable and keep them affordable at the same time. There are two kinds of strategies, one is short-term and the other one is long-term. It is highly possible that medium-sized cities will keep on exporting outstanding people to those large cities in the short future. Therefore, the cities need more high-quality commercial houses, not sumptuous or luxurious, but carefully designed. For those low-income communities, on-site reconstructions with deep indoor investigation are strongly recommended. This method costs less but works better than building low-quality affordable housing in the remote suburban area. If the city is going to become regional center in 20 years, large number of people would flood in and induce an urgent housing shortage. In this case, houses for out-comers should be built in advance to avoid the tragedy of Beijing and Shanghai.

\section{Suggestions: What Should We Do to Keep Houses Affordable?}

An effective housing market is necessary in keeping houses affordable, but many factors including political and economic ones may affect housing market drastically. When policies change, the government should foresee the fluctuation that may happen in housing market and try to keep it effective. No speculation should be permitted.

Legislation is an important support for affordable housing, especially in forbidding housing speculation. The behaviors of local government should be stipulated by laws because they have no strong motivation to provide cheap houses for low-income family. Legal supervision would help to protect low rent housing from being sold out without public participation.

Urban planning should consider more about housing. Housing plan now is only some numbers and has little to do with cities' population and economic development. The scale of affordable housing should be properly controlled to avoid excessive construction. The location should consider the basic infrastructure, including schools, hospitals, commercial facilities and transportation accessibility. Besides, the design of affordable housing, such as the size, the number of rooms and the sunshine direction, should be based on 
the demand of the users, which needs detailed interviews and surveys.

The voices of the public and low-income group should be heard. Investigations and surveys are important in making housing plan. It is regretful that in most of the medium-sized cities, even the big cities, indoor investigations are extremely inadequate. Public participation is conducive to housing affordability in case of "gentrification" and urban regeneration.

Intensive development could also contribute to housing affordability, because it will leave more available land for housing. Most of Chinese cities are developing their lands inefficiently, especially compared with Japanese cities and Korean cities. In the case city, there are still lots of vacant land in inner city, but affordable housing is located in the remote urban fringe.

For the medium-sized city like the case city, it is time to slow down the construction of the affordable housing. There is enough time and great necessity to do research first to find out what to do next.

\section{Reference}

[1] Zou, Y. 2014. "Contradictions in China's Affordable Housing Policy: Goals vs. Structure." Habitat International 41: 8-16.

[2] Cao, J. A., and Keivani R. 2014. "The Limits and Potentials of the Housing Market Enabling Paradigm: An Evaluation of China's Housing Policies from 1998 to 2011." Housing Studies 1: 44-68.

[3] Huang, Y. 2012. "Low-Income Housing in Chinese Cities: Policies and Practices." The China Quarterly 212: 941-64.

[4] Dang, Y., Zhang W., and Liu Z. 2014. "Spatial Distribution and Analysis of Land-Based Influencing Factors of Economical Housing Projects in Beijing." Geographical Research 33: 876-86.

[5] Yang, Z., Yi, C., and Zhang, H. 2010. "Evaluation of the
Housing Affordability in Beijing with the Residual Income Approach." Urban Development Studies 10: 36-40.

[6] Huang, Y. Q. 2004. "Housing Markets, Government Behaviors, and Housing Choice: A Case Study of Three Cities in China." Environment and Planning A 36 (1): 45-68.

[7] Logan, J. R., Bian, Y., and Bian, F. 1999. "Housing Inequality in Urban China in the 1990s." International Journal of Urban and Regional Research 23: 7-25.

[8] Sato, H. 2006. "Housing Inequality and Housing Poverty in Urban China in the Late 1990s." China Economic Review 17: 37-50.

[9] Lin, G. C. S. 2002. "The Growth and Structural Change of Chinese Cities: A Contextual and Geographic Analysis." Cities 5: 299-316.

[10] Kutty, N. K. 2005. "A New Measure of Housing Affordability: Estimates and Analytical Results." Housing Policy Debate 16: 113-142.

[11] Stone, M. E. 2006. "What Is Housing Affordability? The Case for the Residual Income Approach." Housing Policy Debate 17: 151-84.

[12] Gan, Q., and Hill, R. J. 2009. "Measuring Housing Affordability: Looking beyond the Median." Journal of Housing Economics 18: 115-25.

[13] Suhaida, M. S., Tawil, N. M., Hamzah, N., Che-Ani, A. I., Basri, H., and Yuzainee, M. Y. 2011. "Housing Affordability: A Conceptual Overview for House Price Index." Procedia Engineering 20: 346-53.

[14] Mulliner, E., Smallbone, K., and Maliene, V. 2013. "An Assessment of Sustainable Housing Affordability Using a Multiple Criteria Decision Making Method." Omega-International Journal of Management Science 41: 270-9.

[15] Mak, S. W. K., Choy, L. H. T., and Ho, W. K. O. 2007. "Privatization, Housing Conditions and Affordability in the People's Republic of China." Habitat International 31: 177-92.

[16] Cai, W., and Lu, X. 2015. "Housing Affordability: beyond the Income and Price Terms, Using China as a Case Study." Habitat International 47: 169-75.

[17] Wan, J. 2013. "A Case Study of the Problem-Policy Response in the Affordable Housing Construction in Beijing, China." Beijing Planning Review 6: 116-21. 